Information for citation:

Sannikova L. V. Vozmeshchenie poter'v stranakh obshchego prava i v Rossii [Indemnity in Common Law Countries and in Russia]. Vestnik Permskogo Universiteta. Juridicheskie Nauki - Perm University Herald. Juridical Sciences. 2016. Issue 34. Pp. 440-450. (In Russ.). DOI: 10.17072/1995-4190-2016-34-440-450.

UDC 347.4

DOI: 10.17072/1995-4190-2016-34-440-450

\title{
INDEMNITY IN COMMON LAW COUNTRIES AND IN RUSSIA
}

\section{V. Sannikova}

Financial University under the Government of the Russian Federation 49, Leningradsky prospect, Moscow, 125993, Russia Institute of State and Law of the Russian Academy of Sciences 10, Znamenka st., Moscow, 119019, Russia

ORCID: 0000-0002-7250-5062

ResearcherID: K-4636-2016

e-mail: 7718609@mail.ru

Introduction: introduction into the Civil Code of the Russian Federation of a new legal institution of indemnity, borrowed from Anglo-American law, necessitates its comparative legal studies. Purpose: to reveal features of the Russian indemnity statutory concept based on comparative legal studies. Methods: the methodological framework of the research is based on a set of general scientific and specific scientific methods: dialectical, comparative legal, historical, formal legal, linguistic ones. Results: the features of the Russian indemnity concept revealed testify that it is narrower than Anglo-American indemnity in its content and scope of application. Conclusions: the efficacy of the statutory concept under study will depend on the requirements of Russian courts for proving the amount of loss and causal relationships between occurrence of the relevant circumstance and the loss occurrence, in particular on how strict these requirements will be. It is proposed that when recovering loss through court, providing the court has established the fact of occurrence of the circumstance stated by the parties, the occurrence of loss in the amount contracted by the parties should be presumed.

Keywords: indemnity; express or contractual indemnity; equitable or implied indemnity; hold harmless

\section{Information in Russian}

\section{ВОЗМЕЩЕНИЕ ПОТЕРЬ В СТРАНАХ ОБЩЕГО ПРАВА И В РОССИИ}

\section{Л. В. Санникова}

Доктор юридических наук, профессор

Финансовый университет при Правительстве Российской Федерации

ведущий научный сотрудник

125993, Россия, г. Москва, Ленинградский просп., 49

Институт государства и права Российской академии наук

119019, Россия, г. Москва, ул. Знаменка, 10

ORCID: 0000-0002-7250-5062

ResearcherID: K-4636-2016

e-mail: 7718609@mail.ru 
Введение: закрепление в Гражданском кодексе РФ новой правовой конструкции возмещения потерь, заимствованной из англо-американского права, обусловливает необходимость ее сравнительно-правового исследования. Цель: выявить особенности российской конструкции возмещения потерь. Методы: были использованы как общенаучные, так и частнонаучные методы исследования: диалектический, сравнительно-правовой, исторический, формально-юридический, лингвистический. Результаты: выявлены особенности российской конструкиии возмещения потерь, свидетельствующие о том, что российская конструкиия возмещения потерь гораздо у́же англо-американской по своему содержанию и сфере применения. Выводы: эффективность применения исследуемой правовой конструкиии будет зависеть от того, насколько строгие требования будут предъявлять российские суды по доказыванию размера потерь и наличию причинной связи между наступлением соответствующего обстоятельства и возникновением потерь. В связи с этим предлагается при взыскании в судебном порядке возмещения при наличии установленного судом факта наступления обстоятельства, указанного сторонами, презюмировать возникновение потерь в определенном сторонами размере.

Ключевые слова: индемнити; возмещение потерь; подразумеваемый индемнити; контрактный индемнити; ограждение от потерь

\section{Introduction}

Introduction of the Article 406.1 Indemnity into the Civil Code of the Russian Federation and the problems arising in its practical application have revealed the necessity to investigate and compare the mechanism of compensation for loss in Russia and its Anglo-American prototype - indemnity. The research into the indemnity experience in countries of common law is of great significance for working out a balanced approach to adoption of the similar institute within the Russian legal framework.

Section 1 of the present article considers the history of the indemnity concept and its peculiarities in different countries of common law as well as defines the reasons for the introduction of the similar concept into Russian legislation. Section 2 gives the definition to the concept under consideration and characteristics of its particular types. Section 3 deals with the content of this statutory concept in Anglo-American and Russian legal systems. Section 4 considers the relations between the indemnity concept and liability. In the conclusion, the revealed peculiarities of the Russian indemnity statutory concept are enlisted and suggestions are made how to improve the mechanism of its implementation.

\section{The History of the Indemnity Statutory Concept}

The first statutory concept of compensation for loss, or indemnity, comes from the unprecedented legal system of England. In fact, it originated from the equity law. There was a common law rule saying that "compensation without liability is not al- lowed", which in some cases did not let a complainant have a compensation for their property loss. The fact that the aggrieved party is deprived of such an opportunity breaks the principle of justness since it facilitates the unreasoning enrichment of the other party. As a consequence, when delivering a judgment English courts allowed for compensations for loss even in cases there was no liability for them.

The indemnity concept proved to be indemand and got widespread in common law countries. In each jurisdiction, however, its own law enforcement practice was formed, and in a number of countries even a special legal regulation appeared. For example, in India only one kind of indemnity is allowed by law (The Indian Contract Act, 1872), which is a contract of indemnity. In the USA, 50 states adopted anti-indemnity statutes, which considerably restrict the use of indemnity in building contracts. Different approaches to the application of indemnity in England and Norway are referred to by Norwegian researchers. They claim that "While the legal effects of an indemnity clause under English law mainly will depend upon an interpretation of the clause, an indemnity clause under Norwegian law will also be subject to several mandatory rules, such as the general duty of good faith and the standard of reasonableness found in section 36 of the Norwegian Contracts Act" [12].

Of special notice is the fact that the indemnity concept is used in international contracts, which generally obey common law [17]. This very aspect became the main reason for the establishment of a 
very similar to indemnity institute of compensation for loss in the Civil Code of the Russian Federation. Although introduction of this institution into Russia's civil legislation was not provided for by The Concept of the Development of Civil Legislation, the ambitious plans to create the International Financial Center in Russia brought Art. 406.1 Indemnity into the Civil Code of the Russian Federation. The authors of the article, who managed to remain unknown, were planning that this legal institute along with other legislative innovations, mostly of Anglo-American origin, would make the Russian regulatory environment more facilitative for international business.

However, the plans concerning the International Financial Center failed to come true, and due to the economic sanctions foreign investors are not interested in doing business in the country. Nevertheless, the updated civil legislation contains a number of statutory concepts and institutions borrowed from other countries, including the concept of indemnity. At the same time, the legislative content is presented in such a way that businesses which actively supported legalization of statutory concepts from common law countries now see numerous legal risks if applying them in Russia. Thus, having all this in mind law executors have to adapt new statutory concepts to the Russian legal system.

\section{Indemnity. Definition of the Concept and Its Types}

There is no legal definition of the concept of indemnity, as it is obvious from its precedent nature, but neither there are any controversies in understanding the legal nature of this phenomenon. Generally, indemnity is considered to be a promise of one party to compensate loss suffered by the other party and/or hold it harmless. According to W. Courtney, "the term 'indemnity' is elastic. It may describe a process or arrangement under which a party will not suffer any loss" [13].

Classification of indemnity can give us a more complete idea of this concept.

In Anglo-American law, indemnity may come from the essence of the obligation occurred between two parties (equitable or implied indemnity) or it can be set by an agreement of parties (express or contractual indemnity). According to J. Gray, the concept of equitable indemnity "allows courts to shifts liability to a part who they believe is most responsible for an injury" [16]. Equitable indemnity is applied to torts, while contractual relationship uses implied contractual indemnity. In judicial acts referred to by J. Gray it is explained that "implied contractual indemnity is premised on the notion that a contract to perform a service contains an implied promise that the services will be performed in proper manner. From this promise, the courts imply an obligation to indemnify the promise for any foreseeable damages resulting from improper performance of the contract" [16].

Express contractual indemnity is a promise of one party to pay a certain sum of money to the other party in the case of occurrence of circumstances (events or actions) provided for by the indemnity agreement. Practicing lawyers say that "the court's focus is on the expressed intent of the parties, rather than principles of fairness and equity (although express indemnity clauses will be strictly construed as narrowly as possible to prevent overreaching)" [10].

The freedom of parties when working out these conditions gives rise to multiple variations of the indemnity clause. Nevertheless, it is possible to define the most common indemnity types [9]:

Bare indemnity is when one party (referred to below as party A) indemnifies the other party (referred to below as party B) for all liabilities or losses incurred in connection with specified events or circumstances, but without any specific limitations;

Reverse indemnity is when party A indemnifies party B against losses incurred as a result of party B's own acts and/ or omissions (mostly party B's own negligence). This type of indemnity is most frequent in oil and gas industry, where the probability of loss is high due to the increased danger of production processes;

Proportionate or limited indemnity is when party A indemnifies party B against losses except those incurred as a result of party B's own acts and/ or omissions;

Third party indemnity is when party A indemnifies party B against liabilities to claims by par- 
ty C. It is mostly used when tax orders are concerned;

Party-to party indemnity is when each party to a contract indemnifies the other(s) for losses occasioned by the indemnifier's breach of the contract;

Financing indemnity is when party A indemnifies party $\mathrm{B}$ against losses incurred if party $\mathrm{C}$ fails to honor the financial obligation (i. e. the primary obligation) to party B (most often these are coupled with a guarantee).

In Russian legislation, the statutory concept of indemnity is clarified in Cl. 1 Art. 406.1 of the Civil Code of the Russian as "an obligation of a party to compensate the other party for losses". A. L. Makovsky describes the indemnity institute as an institute "where one party of the agreement, despite its irreproachable conduct, shares responsibility for the consequences in no way connected with its conduct" [5]. The circumstances agreed by the parties in the indemnity agreement and not connected with the breach of the contract obligations by one of the parties could serve as rationale for the compensation. Resolution of the Plenum of the Supreme Court of the Russian Federation No. 7 dated 24 March 2016 "On the Application by Courts of Certain Provisions of the Civil Code of the Russian Federation Concerning Liability for a Breach of Obligations" specified that it concerns not any circumstances enlisted by the parties but those somehow connected with performance, alteration or termination of the obligations between the parties or with the object of the obligation. What is more, only circumstances that are not connected with violation of obligations can be treated as those listed above. Article 406.1 of the Civil Code of the Russian Federation provides an open-ended list of such circumstances: impossibility of performance of the obligation, a request submitted to one of the parties or a third party mentioned in the agreement by the government authorities or some third party.

Thus, Russian legislation only admits indemnity based on the agreement between the parties. However, it would be wrong to restrict the scope of this institution with conventional law since parties can enter into an agreement in the case of a delictual obligation.

One more peculiarity of Russian legal regulation of indemnity is the fact that only those con- ducting entrepreneurial activity can act as the parties in this agreement. The law does not state whether it is a commercial organization that can act as a party in the indemnity agreement, which makes it possible to conclude that non-commercial organizations can also do so providing they conduct entrepreneurial activity. The exception to the rule (Cl. 5 Art. 406.1 of the Civil Code of the Russian Federation) is provided for physical persons participating in corporate agreements or agreements on alienation of shares in charter capital of an economic society.

Speaking about types of indemnity, it is safe to say that compensation for loss at the request of the third party is the only type familiar to AngloAmerican law. And according to the clear statement of law, the third party can be represented by the government authorities (taxing authorities, custom authorities, etc.) along with commercial organizations and individual entrepreneurs. As a private lawyer E. A. Segalova notices, in Russian practice of shares purchase and sale based on English law, the period of validity of indemnity obligations is 6 7 years after the transaction is closed. This concerns taxing issues as well as the most important ones detected during a legal review [7].

A special notice should be made of the opportunity for the parties to establish an obligation to compensate for loss having resulted from the actions of the third party. The law does not state it directly but $\mathrm{Cl} .18$ of the Resolution of the Plenum of the Supreme Court of the Russian Federation No. 7 sets the effects when compensation for losses occurred due to the third party's wrong actions. The party having compensated for such losses gets entitled to require from the third party to pay for damages in the amount not exceeding the sum it had spent on compensation for the losses. If the amount of loss compensated exceeds the amount of damages to be compensated, the difference is not levied from the third party as the indemnity agreement does not bind it.

Financial recompense is also assumable as a type of indemnity. It is likely to be in great demand due to the extending scope of persons who can be guarantors in an independent guarantee. If the guarantee is given not by a bank or an insurance company but by a commercial organization, some addi- 
tional security could be required; in this case, an indemnity agreement can serve as such a guarantee.

Some other types of indemnity familiar to Anglo-American law could be stated in an agreement depending on the answer to the question whether the circumstance provided for in the indemnity agreement can occur as a result of action of the indemnified party.

According to the law, circumstances creating indemnity obligations have two characteristics. First, they must be defined in the indemnity agreement; second, they must be non-connected with violation of the obligation by its party. Literal interpretation of Cl. 1 Art. 406.1 of the Civil Code of the Russian Federation states that if the circumstances occurred as a result of action of the indemnified party, including its carelessness or negligence, but cannot be qualified as violation of the obligation, then losses are to be compensated. The Supreme Court only makes an exception for the case when the party whose loss is to be compensated assisted to the occurrence of these circumstances from bad faith. The circumstance given is considered to be non-occurred and the loss is not compensated to the unfair party $(\mathrm{Cl} .15$ of the Resolution of the Plenum of the Supreme Court of the Russian Federation No. 7).

Consequently, in their indemnity agreement participants of the property turnover are entitled to mention unintended actions of the indemnified party as circumstances invoking indemnity obligation (i. e. parties can envisage so called reverse indemnity).

For instance, in an independent-work contract a company can assume the obligation to compensate for the loss to the contractor in case the equipment involved breaks down even if the breakage or loss resulted from the action of the contractor, including negligence. However, there is an opposite opinion about it: "The right of the contractor to the compensation for loss occurred as a result of loss of the equipment in a well is considerably restricted. The obligation of the company to pay out the cost of the lost equipment only appears in case there is no fault of the contractor. If the fact that the loss of the equipment was caused by the contractor's negligence is proved, the company will be released from the above obligation. This fact contradicts the best practice of service in oil industry, according to which the degree of the contractor's guilt is to be leveled to a one-man gross negligence so that the company would be able to refuse to compensate the cost of the lost equipment" [1]. Thus, it appears that application of the provisions of Art. 406.1 of the Civil Code of the Russian Federation will contribute to the concordance between Russian and world-wide law enforcement practice.

\section{Content of the Indemnity Agreement}

Precise wording of the conditions of compensation for loss is of great importance in resolution of legal cases. As it is noticed by foreign researchers: "Traditionally the general approach of the courts towards exemption clauses has been a hostile one, and the courts tend to look more critically at these clauses than other types of contract clauses" [12].

As a rule, an indemnity clause uses two terms, which are "indemnity" and "hold harmless". Their relation and the part they play in the contractual concept of indemnity are discussible in English literature. As A. G. Arkhipova [2] reasonably noted, some authors consider indemnity obligation and hold harmless obligation independent of each other and having different contents and places of origin. However, an indemnity clause in agreements is formulated as "indemnity and hold harmless" for the same indemnity case. To understand the nature of these controversies, it should be noted that they are not English but American lawyers who emphasize the expression "hold harmless".

A vocal opponent of this approach is B. Garner [14], who conducted an etymological analysis of the words "indemnity" and "hold harmless" and proved their synonymy: "indemnity" comes from Latin and "hold harmless" is of the Anglo-Saxon origin. However, despite this finding, he has to admit that American courts have been differentiating them since the late $19^{\text {th }}$ century: "There is a distinction between 'indemnify' and 'save harmless,' the latter phrase possessing the more extensive meaning" (Weller v. Eames, 15 Minn. 461, 467(1870) [Cited from 14]. 
In particular, if a contract clause includes the expressions "hold harmless" or "save harmless" or "keep harmless" it allows for collecting court fees for barristers, which is not provided by law in the USA, unlike England. That is why American barristers insist on inclusion of these expressions into the contract in order to avoid any misinterpretation. They point out that having such expressions as "shall not be liable for" or "agrees to assume" is generally not enough to create an effective and enforceable clause of an indemnity agreement [15].

At the same time, an Australian man of law W. Courtney states that an indemnity clause may lack words "hold harmless", "save harmless" or "keep harmless", saying that "the traditional drafting 'to indemnify and save harmless' appears nowadays to be tautological, though the expression may be intended to emphasize that the indemnity is to receive a preventative construction" [13].

The variety of opinions on this issue in English literature shows that practice of application of this or that concept varies depending on a certain jurisdiction. Nevertheless, a number of legal scholars, mostly American and Australian ones, think that the expression "hold harmless" stands for a selfcontained liability for securing the other party of the agreement against any potential loss through providing legal assistance, involvement into court proceedings, conduct of the case, etc.

Thus, the indemnity concept includes not only compensation for incurred and potential loss but also an obligation to secure the other party against any possible loss.

The amount of compensation will depend on how the party's indemnity liability will be defined. Therefore, courts require clear and unequivocal statements for indemnity clauses. As a rule, parties use the phrase "all loss", allowing for covering various adverse effects: "liabilities, obligations, damages, actions, suits, proceedings claims, demands, assessments, judgments, costs, penalties and expenses, including reasonable attorney's fees and disbursements" [20]. At the same time, indemnification provisions "may also set a cap on the maximum amount that may be recoverable thereunder, contain exclusions from recoverable losses below certain thresholds or deductibles, and provide for certain categories of losses (most notably, "consequential losses") that are simply not recoverable under any circumstance" [20].

In Russian law, the content of the indemnity concept is restricted by either compensation for loss sustained or that unavoidable in the future. The exact wording holding the party to compensate for loss is also of great importance. While in an English court any discrepancy in indemnity agreements can just shake the position of the party requiring compensation for loss, a Russian court can refuse to apply the clauses of Art. 406.01 of the Civil Code of the Russian Federation if it finds the indemnity agreement insufficiently clear or unequivocal. When making up the indemnity clause, the parties are not only to make reference to Art. 406.1 of the Civil Code of the Russian Federation but also to define the circumstances due to which the loss is to be compensated as well as the amount of compensation or the order of its determination.

The law (Cl. 1 Art. 406) insists on specifying the amount of compensation or the procedure for its determination in an indemnity agreement. However, the above requirement does not correspond with the practice in countries with the Anglo-American system of law, where the parties just stipulate but not specify the amount of compensation. The amount of potential loss stated in the agreement would mean that the parties have agreed about liquidated damages but not about compensation for loss. It is impossible to evaluate in advance the damages that could occur under certain circumstances.

Thereby the legislator's provisions on the liability of parties to agree about the amount of compensation or the order of its determination are considered by A. G. Karapetov as a "misconception" or "editorial inconsistency" [4], which seems to be fair to some extent. However, another reason can serve as a counterargument here.

In spite of the fact that Russian indemnity legislation is relatively loyal, there is a significant problem concerning recovery of compensation, as it is very difficult to prove the amount of loss sustained. Probably, when providing parties with the possibility to estimate the amount of potential loss, the legislator meant to provide the real op- 
portunity for loss to be recovered. It is confirmed by a rule in Cl. 2 Art. 406.1 of the Civil Code of the Russian Federation which forbids the court to reduce the amount of compensation.

A. G. Karapetov suggests considering the amount of compensation agreed in the contract to be the limit of compensation. Such interpretation, however, will also allow the courts to recover damages lower than the prescribed limit with the reference to the understatement of the amount of damages.

At the same time, in some particular cases the exact amount of loss can be reasonably determined by the parties. V. N. Anurov [1] gives an interesting example from Russian judicial practice. The defeasance clause stated that "according to clause 8.3 of the contract, as amended by the additional agreement No. 1, the company is held liable for damages caused to the contractor's equipment and confirmed by the act signed by the parties in the following way: if the equipment is lost and impossible to be recovered, the company is to pay in at the prices stated in appendix No. 9 of the additional agreement No. 1; if the equipment is damaged, it is paid in the amount necessary for its complete recovery. The article given does not cover the loss or damage of the equipment caused solely by the actions of the contractor".

Considering this defeasance clause in terms of potential application of the regulations from Art. 406.1 of the Civil Code of the Russian Federation, it is possible to consider the prices agreed by the parties in the case of loss of the equipment as an amount of compensation. The statement that when the equipment is lost its cost should be paid in completely and when it is damaged the cost of the recovery is to be compensated can be seen as a method for determining the amount of compensation. $\mathrm{Cl} .15$ of the Resolution of the Plenum of the Supreme Court of the Russian Federation No. 7 provides another example of "such procedure for determining the amount of loss, when one of the parties compensates the other party either for all the loss caused by the corresponding circumstances or for their part".

Nevertheless, some worries expressed by A. G. Karapetov look reasonable as when treated literally, "compensation for loss turns into payment of some abstract sum of money, the amount of which is not connected with real damages occurred" [4]. E. A. Ostanina also assumes that due to some agreement disparity the amount of loss might "pre- determinedly have no economical prove or be overvalued, which would cause an unjust enrichment of the indemnified party" [6]. Presumably, according to Cl. 15 of the Resolution of the Plenum of the Supreme Court of the Russian Federation No. 7, compensation for loss is only available when loss is proved to have occurred or to occur in the future.

\section{Indemnity and Liability}

The additional real obligation imposed on a party of the agreement makes the statutory concept under discussion similar to liability; that is why it is necessary to draw a clear distinction between them.

According to Anglo-American law, an indemnity agreement can be concluded even for the case of violation of the contract, so in Anglo-American legal literature the relation between indemnity and liability is given special attention. The advantage of indemnity is seen in the fact that when compensation for loss takes place general principles of recovery of damages [19] are not applied since indemnity is not a kind of liability. Another principle which is not applied to indemnity is that of mitigation, according to which the disadvantaged party has to take reasonable measures to reduce the amount of damages. The principle of remoteness is not applicable either as it requires damages to occur in the course of an ordinary scenario caused by the violation of the agreement and to be reasonably foreseen by the parties. It is emphasized that "proof of damages may be more difficult than proving "out of pocket" losses and expenses for indemnification" [11]. It would let the disadvantaged party of the agreement get the utmost compensation for unfavorable property consequences.

Meanwhile, A. V. Tosminov believes that "in judicial practice there is a gradual convergence of compensation for loss connected with the circumstance which is at the same time a breach of the agreement and recovery of damages on the principles applied" [8]. Actually, in certain cases courts applied the remoteness and mitigation principles towards indemnity (Royscot Commercial Leasing Ltd v Ismail; The Eurus). Nevertheless, foreign researchers do not see here any trends towards the convergence of liability and indemnity. When mentioning that remoteness and mitigation can be applied to indemnity when it is set for the case of breach of an agreement, they underline the possibility for the parties to exclude these limitations in 
case of clear and correct wording of the contract, in another words providing the use of some form of express language [12].

It has also to be noted that application of the contractual indemnity does not always comply with the principle of justness. For example, indemnity clauses can exclude a party's responsibility for its own negligence. Such liability restriction is of common use in building contracts made in the USA, where owners and general constructors used to shift all the risks onto a subcontracting party. In this connection, 50 American states adopted antiindemnity statutes, which significantly restricted the use of indemnity in building contracts. Moreover, restrictions are established in public contracts too: "the federal government is subject to unique contractual limitations, one of which restricts the means and scope of contractual indemnification in federal government contracts" [18].

In Russian civil law, the issue of the relations between the indemnity institution and liability is the result of the introduction of Art. 406.1 into the Chapter 27 "Liability for Breach of an Obligation" of the Civil Code of the Russian Federation. This decision of law drafters may seem quite ambivalent. S. Yu. Filippova notes that unlike liability, which is the consequence of an obligor's offending behavior having caused unfavorable property effects for the creditor, the loss set in the above mentioned article can be passed to the obligor even if indemnity obligations were not violated and there is no cause-andeffect relations between the obligor's behavior and the damages caused to the creditor [3].

The regulations of Art. 406.1 of the Civil Code of the Russian Federation imply that this protective measure is not applicable to cases of breach of obligation. The expression "non-connected with breach of obligation by their party" from $\mathrm{Cl} .1$ Art. 406.1 can be interpreted as follows: unlike Anglo-American law, Russian legislation does not provide a possibility of compensation for loss in case one of the parties has violated its obligations.

Nonetheless, according to the Resolution of the Plenum of the Supreme Court of the Russian Federation No. 7, the indemnity obligation not only arises from the circumstances which "are not breach of the obligation" but also takes place "regardless of the fact of breach of obligation (non- performance or improper performance) by the corresponding party and regardless of casual connection between this party's behavior and loss to be compensated".

This interpretation seems rather controversial as the expression "regardless" admits the possibility that the indemnity agreement will extend to the cases when loss occurred due to non-performance or improper performance of the obligations by one of the parties, including the one that is to pay indemnification. Moreover, in a number of cases it is rather difficult to differentiate between the breach of obligation and the circumstance entailing the indemnity obligation.

Let us consider the potential functioning of the indemnity concept through the following example: parties of an independent contractor agreement agreed about a certain amount of compensation for loss if the company does not get permit for work performance. This situation can be a result of both the company's actions failing to commit all the necessary procedures to get this permit or making some mistakes in documents involved and actions of some third parties, which might be an agency responsible for issuing those permits (including illegitimate ones). The question is whether the court, when hearing the compensation for loss case, must investigate the cause of the circumstance having entailed the loss as well as the casual connection between this circumstance and the company's actions. Probably not, as the legislative framework for the institution of indemnity will lose its sense. The function of the court is just to establish the fact that this circumstance has occurred.

However, even if this has been successfully done and the amount of loss has also been determined, it is not enough for the legal recovery procedure. According to $\mathrm{Cl} .15$ of the Resolution of the Plenum of the Supreme Court of the Russian Federation No. 7, the indemnified party has to prove casual connection between the circumstance causing losses and the losses themselves, as well as the fact of them being either sustained or unavoidable in the future.

Such a complicated system of evidence for damages or loss sustained will hardly allow the compensation for loss concept to become more efficient than compensation for damages. According 
to the example, if the contractor explains that they could not embark on work in due time, which led to damages caused by the forced downtime, then the contractor can claim compensation as a loss of expected gain. And there is no necessity to prove the client's fault since their liability incurs regardless of their fault (Cl. 3 Art. 401 of the Civil Code of the Russian Federation). However, as practice shows, loss of expected gain in Russian courts is hardly ever recovered due to its difficulty to be proven. And the same difficulties are supposed to arise when applying the compensation for loss concept in the court.

It should be noted that the interpretation suggested by the Supreme Court of the Russian Federation fully complies with the common practice of applying this statutory concept in Anglo-American law. However, in these countries such practice does not prevent using the indemnity concept as an alternative to a party's liability for breach of an agreement, which allows for avoiding restrictions concerning the liability of the parties. In Russia such law enforcement practice would bring all the legislator's attempts to nothing.

It seems that the implementation mechanism for the indemnity concept should be of another kind. If in the above example there is a clause establishing compensation for loss and its amount in case the contractor does not receive a permit for work performance, then when hearing the case about compensation the court only needs to establish that this permit has not been given. If such a fact has been established, compensation for loss in the amount agreed by the parties should be presumed. The presumption is possible to be disapproved by the party liable to compensate but in this case the burden of proof lies with this very party. In exceptional cases, when it is obvious that the amount of loss is not economically justified and has resulted from certain contract disparity, the intervention of the court makes sense as it can apply the principle of good faith and reduce the compensation amount pursuant to Art. 10 of the Civil Code of the Russian Federation.

Under such an approach, the Russian concept of indemnity will resemble stipulated damages in terms of Anglo-American law, but this is the only way to make it work properly. Otherwise, the Russian indemnity concept, which is rather sketchy compared to its Anglo-American ancestor, could be only applied towards a narrow range of cases being of the force majeure nature.

\section{Conclusions}

Legal analysis aimed to compare the indemnity statutory concept in Anglo-American law and that in Russian legislation allowed us to reveal the following peculiarities of the latter:

1) compensation for loss is only possible based on an agreement between the parties;

2) the content of the indemnity concept only involves the obligation to compensate for the loss sustained or unavoidable in the future but does not provide the hold harmless obligation;

3) the parties are to determine the amount of compensation or establish the procedure for its determining in the agreement;

4) the indemnity obligation can only be established under circumstances non-connected with breach of the obligation by one of the parties.

Thus, the Russian concept of indemnity is considerably narrower than the Anglo-American one in terms of its content and scope of application. Nevertheless, it allows parties to incorporate into agreements the types of indemnity most common in Anglo-American law.

Russian courts apply to the concept the same severe requirements for establishing the amount of loss and cause-and effect relationship between the corresponding circumstance and the occurrence of the loss, which will not allow for effective use of this statutory concept for sharing risks resulting from the parties' entrepreneurial activity. In order to enhance the mechanism for the implementation of the indemnity concept, it is suggested that when recovering loss, providing the circumstance the parties had agreed about was established by the court, there should be presumption of the occurrence of loss in the amount contracted by the parties.

It is only under the above-stated conditions that the concept of indemnity could be successfully integrated into the remedy system of Russian civil law.

\section{References}

1. Anurov V. N. Vozmeshchenie poter' $v$ nefteservisnykh dogovorakh [Compensation for Losses in Oilfield Service Contracts]. Moscow, 2016. 232 p. (In Russ.). 
2. Arkhipova A. G. Vozmeshchenie poter'v novom GK RF: "za" ili "protiv"? [Compensation for Losses in the new Civil Code of the Russian Federation: "Pro" or "Contra"?]. Vestnik grazhdanskogo prava - Civil Law Review. 2012. № 4. Pp. 158-183. (In Russ.).

3. Grazhdanskiy kodeks Rossiyskoy Federatsii. Postateynyj kommentariy $k$ razdelu III «Obshchaya chast' obyazatel'stvennogo prava»; pod red. L. V. Sannikovoy [The Civil Code of the Russian Federation. Commentary to the Section III "The General Part of Contractual Law"; ed. by L. V. Sannikova]. Moscow, 2016. 622 p. (In Russ.).

4. Karapetov A. G. Zavereniya ob obstoyatel'stvakh i usloviya o vozmeshchenii poter' $v$ novoy redaktsii GK RF [Representations and Provisions for Recovery of Losses in the New Version of the Civil Code of the Russian Federation]. Zakon - ZAKON. 2015. № 6. Pp. 43-56. (In Russ.).

5. Makovskiy A. L. Ob urokakh reformirovaniya Grazhdanskogo kodeksa Rossii [On the Lessons of Reforming the Civil Code of Russia]. Vestnik grazhdanskogo prava - Civil Law Review. 2013. № 5. Pp. 157-172. (In Russ.).

6. Ostanina E. A. Sud'ba indemniti pri nesostoyatel'nosti dolzhnika [Indemnity in Case the Debtor is Insolvent]. Zakon - ZAKON. 2015. № 7. Pp. 56-63. (In Russ.).

7. Segalova E. A. Ogranicheniya zavereniy, garantiy i obyazatel 'stv po vozmeshcheniyu poter' $v$ dogovore kupli-prodazhi aktsiy (doley) po angliyskomu pravu [Limitations of Representations, Warranties and Indemnity Obligations in the Contract of Shares Purchase and Sale under English Law]. Access from the legal reference system ConsultantPlus. (In Russ.).

8. Tomsinov A. V. Mesto indemnity v rossiyskom grazhdanskom prave [The Place of Indemnity in the Russian Civil Law]. Moskovskiy yurist Moscow lawyer. 2013. № 1. Pp. 56-64. (In Russ.).

9. Alderman $P$. Indemnity Clauses in Commercial Contracts: How to Achieve Desired Contractual Risk Allocation. 2011. Australia. Available at: http:// www.lexology.com/library/detail.aspx?g $=\mathrm{db} 38 \mathrm{e} 8 \mathrm{~d} 6-7451-49 \mathrm{e} 1-9 \mathrm{e} 74-531 \mathrm{bf32} \mathrm{e} 0 \mathrm{~d} 10 \quad(\mathrm{ac}-$ cessed 10.07.2016). (In Eng.).

10. An Overview of Indemnification and the Duty to Defend. ACES. 2014. Available at: http://docs. acec.org/pub/DA77E02A-C742-9915-1727-73D F2CCC23B9 (accessed 22.06.2016). (In Eng.).

11. Booth P. J. Problems with Contractual Indemnities (and How to Avoid Them). Available at: http://www.gordonandjackson.com.au/uploads /documents/seminar-papers/Problems_with_
Contractual_Indemnities_-_Peter_Booth.PDF. (In Eng.).

12. Bjerketveit A. Indemnity - and Hold Harmless Clauses. Available at: http://www.jus.uio.no/ ifp/english/research/projects/anglo/essays/bjerk etveit_abstract.pdf. (In Eng.).

13. Courtney $W$. The Nature of Contractual Indemnities. Legal Studies Research Paper. 2011. August. № 11/41. (In Eng.).

14. Garner B.A. Indemnify. Green Bag 2d. 2011. Vol. 15. (In Eng.).

15. Gesellschap V.A., Hicks R. L. The Interplay Between Indemnification Provisions and Insurance Clauses in Contracts for Goods and Services. Available at: http://www.osbcorporatecounsel.com/2014-066 ArticleonindemnificationandinsurancefromACCDocket.pdf. (In Eng.).

16. Gray J. J. F. Implied Contractual Indemnity: An Infirm Doctrine Whose Time Has Passed. Loy. LAL Rev. 1988. Vol. 22. (In Eng.).

17. Macattram $G$. How Can the Indemnity Clause Expand or Limit the Responsibility of the Parties in International Oil and Gas Contracts? Available at: http://www.dundee.ac.uk/cepmlp/ car/htmlcar1editorial.php. (In Eng.).

18. O'Connell S. M. Contractual Indemnification by the Federal Government. Law School Student Scholarship. 2014. Paper 279. Available at: http://scholarship.shu.edu/student_scholarship/279. (In Eng.).

19. Posner E. A. Contract Remedies: Foreseeability, Precaution, Causation and Mitigation. Bouckaert B. De Geest G. (eds.), Encyclopedia of Law and Economics. 2000. (In Eng.).

20. West G. D., Duran S. G. Reassessing the "Consequences" of Consequential Damage Waivers in Acquisition Agreements. The Business Lawyer. 2008. Pp. 777-807. (In Eng.).

\section{References in Russian}

1. Ануров В. Н. Возмещение потерь в нефтесервисных договорах. М.: Инфротропик, 2016. $232 \mathrm{c}$.

2. Архипова А. Г. Возмещение потерь в новом ГК РФ: «за» или «против»? // Вестник гражданского права. 2012. № 4. С. 158-183.

3. Гражданский кодекс Российской Федерации. Постатейный комментарий к разделу III «Общая часть обязательственного права» / под ред. Л. В. Санниковой. М.: Статут, 2016. $622 \mathrm{c}$.

4. Карапетов А. Г. Заверения об обстоятельствах и условия о возмещении потерь в новой редакции ГК РФ // Закон. 2015. № 6. C. 43-56. 
5. Маковский А. Л. Об уроках реформирования Гражданского кодекса России // Вестник гражданского права. 2013. № 5. С. 157-172.

6. Останина E. A. Судьба индемнити при несостоятельности должника // Закон. 2015. № 7. C. 56-63.

7. Сегалова Е.А. Ограничения заверений, гарантий и обязательств по возмещению потерь в договоре купли-продажи акций (долей) по английскому праву [Электронный ресурс]. Доступ из справ.-правовой системы «Консультант Плюс».

8. Томсинов А. В. Место indemnity в российском гражданском праве // Московский юрист. 2013. № 1. С. 56-64.

9. Alderman P. Indemnity Clauses in Commercial Contracts: How to Achieve Desired Contractual Risk Allocation. 2011. Australia. URL: http:// www.lexology.com/library/detail.aspx?g=db38 e8d6-7451-49e1-9e74-531bf32e0d10 (дата обращения: 10.07.2016).

10. An Overview of Indemnification and The Duty to Defend // ACES. 2014. URL: http://docs. acec.org/pub/DA77E02A-C742-9915-1727-73 DF2CCC23B9 (дата обращения: 22.06. 2016).

11. Booth P. J. Problems with Contractual Indemnities (and How to Avoid Them). URL: http://www.gordonandjackson.com.au/uploads/ documents/seminar-papers/Problems_with_Contractual_Indemnities_-_Peter_Booth.PDF (дата обращения: 13.07.2016).

12. Bjerketveit A. Indemnity - and Hold Harmless Clauses. 28 p. URL: http://www.jus.uio.no/ifp/ english/research/projects/anglo/essays/bjerketveit_abstract.pdf (дата обращения: 17.07.2016).
13. Courtney $W$. The Nature of Contractual Indemnities // Legal Studies Research Paper. 2011. August. № 11/41.

14. Garner B. A. Indemnify // Green Bag 2d. 2011. Vol. 15.

15. Gesellschap V.A., Hicks R. L. The Interplay Between Indemnification Provisions and Insurance Clauses in Contracts for Goods and Services. URL: http://www.osbcorporatecounsel. com/2014-066 ArticleonindemnificationandinsurancefromACCDocket.pdf. (дата обращения: 15.07.2016).

16. Gray J. J. F. Implied Contractual Indemnity: An Infirm Doctrine Whose Time Has Passed // Loy. LAL Rev. 1988. Vol. 22.

17. Macattram $G$. How Can the Indemnity Clause Expand or Limit the Responsibility of the Parties in International Oil and Gas Contracts? URL: http://www.dundee.ac.uk/cepmlp/car/ htmlcar1 editorial.php. (дата обращения: 11.07.2016).

18. O'Connell S. M. Contractual Indemnification by the Federal Government // Law School Student Scholarship. 2014. Paper 279. URL: http://scholarship.shu.edu/student_scholarship/ 279 (дата обращения: 10.07.2016).

19. Posner E. A. Contract Remedies: Foreseeability, Precaution, Causation and Mitigation // Bouckaert, B.-G. De Geest (eds.), Encyclopedia of Law and Economics. 2000.

21. West G. D., Duran S. G. Reassessing the "Consequences" of Consequential Damage Waivers in Acquisition Agreements // The Business Lawyer. 2008. Pp. 777-807. 